\title{
Assessment of Pigeonpea Restorers on Morphological Basis of Host Plant Resistance against Pod Borers
}

\author{
Sukanya Machanwar ${ }^{1}$ and Sanjeev Bantewad ${ }^{2 *}$ \\ ${ }^{1}$ Department of Entomology, Vasantrao Naik Marathwada Krishi Vidyapeeth (VNMKV), \\ COA, Badnapur, India \\ ${ }^{2}$ Department of Agriculture Entomology, Vasantrao Naik Marathwada Krishi Vidyapeeth \\ (VNMKV), Parbhani (MS), India \\ *Corresponding author
}

\section{A B S T R A C T}

\begin{tabular}{|l|}
\hline Ke y w o r d s \\
Restorers, \\
Morphological \\
characters, \\
Pigeonpea pod \\
borer
\end{tabular}

\section{Introduction}

Pigeonpea (Cajanus cajan L.) is one of the major grain legume crops in the tropical and subtropical regions of the world (Singhal, 2003). It is the second important pulse crop of India after chickpea and commonly known as arhar or red gram. It is a rich protein source and affords a major share of the protein requirement in the vegetarian diet in our country. It is an important source of high quality dietary protein and is mostly consumed in the form of split pulse; green seeds are used as a vegetable. It is an agricultural crop of 
rainfed dry lands, which can be grown on mountain slopes to reduce soil erosion. As pigeonpea is a leguminous plant, it can fix atmospheric nitrogen and enriches the soil. Pigeonpea are frequently inter-planted with other short term crops, including cereals and other grain legumes, for higher productivity per unit land area and reduced risks associated with some crop failures.

In India pigeonpea is grown in an area of 4.42 million hectares with an annual production of about 4.02 million tonnes and the average productivity is $909 \mathrm{~kg} / \mathrm{ha}$., whereas, in Maharashtra, pigeonpea is cultivated in an area of 12.28 lakh hectares with an annual production of 9.83 lakh tonnes and the average productivity is $800 \mathrm{~kg} / \mathrm{ha}$ and Marathwada region, area under pigeonpea 4.56 lakh hectares with a annual production of 3.80 lakh tonnes and average productivity is $789 \mathrm{~kg} / \mathrm{ha}$., during 2017-18 (Anonymous, 2018).

Over 250 species of insects belonging to 8 orders and 61 families have been found to attack the pigeonpea of these, the gram pod borer, Helicpverpa armigera (Hubner), tur plume moth, Exelastis atomosa (Walsingham) and pod fly, Melanogromyza obtusa (Malloch) are important feeder of pigeonpea which are collectively referred to as the pod borer complex which significantly reduces the crop yield to an extent of 60 to 90 per cent (Lal and Katti, 1998). Pigeonpea yields have remained stagnant for the past 3 to 4 decades, largely due to damage inflicted by insect pests. Amongst many other insect pests attacking pigeonpea crop as tur pod bug, Clavigralla gibbosa (Spinola), legume pod borer, Maruca vitrata (Geyer) causes significant reduction in the crop yield of pigeonpea (Sujithra and Chander, 2014). As per a conservative estimate, losses due to these insect pests may vary from 27 per cent to even 100 per cent in pigeonpea (Srilaxmi and Paul, 2010). The losses due to pigeonpea pod borers during
1984-85 and 1985-86 were reported to be 52.74 and 8.33 percent in cultivar UPSC120, 62.02 and 56.83 per cent in cultivar BDN-1 and 64.37 and 58.35 percent in G 3, respectively (Sharma and Pandey, 1993). The early, medium and late maturing cultivars of pigeonpea were reported to be damaged by $M$. obtusa and $H$. armigera to the tune of 29.55 to $55.63,20.95$ to 57.00 and 32.92 to 56.56 percent, respectively (Shrivastava et al., 1993), pigeonpea pod damage to the insects varied from 7.6 to 31 percent.

Development of cultivars resistant to this pest has a greater potential for integrated pest management, particularly under subsistence farming conditions in the developing countries (Fitt, 1989). Several morphological traits such as pod toughness, structure of pod wall, and trichomes on the pod surface have been reported to be associated with resistance to $H$. armigera (Shanower et al., 1997). Besides the morphological traits, chemical compounds intrichome exudates and on pod wall surface also influence the host plant selection and colonization by $H$. armigera (Green et al., 2003).

Therefore, there is urgent need to evaluate promising genotypes and select the promising genotypes having desirable morphological characters to combat the ravages caused by Helicoverpa armigera, Maruca vitrata and other pod borers in pigeonpea.

\section{Materials and Methods}

A screening trial was laid out in RBD design against the pod borers in the Experimental field of Entomology, Agricultural Research Station, Badnapur, Vasantrao Naik Marathwada Krishi Vidyapeeth, Parbhani during Kharif, 2017-18. The experimental material comprised of twenty six promising restorers was procured from Breeding section, ARS, Badnapur. Each restorer was sown in 
four rows of $4 \mathrm{~m}$ lengths with the spacing of $90 \mathrm{~cm}$ between the rows and $20 \mathrm{~cm}$ within the row likewise three replications were maintained. The crop was raised following all the recommended agronomic practices and kept free from insecticidal sprays. An experiment was planned in such a way that the restorers were exposed to the peak abundance of pod borer complex. The observations on the incidence of $G$. critica, $H$. armigera, $E$. atomosa, M. obtusa and No. of webbing by Maruca vitrata was recorded weekly.

Data on damaged and healthy pods in each cultivar were recorded from the pods after harvest and per cent pod and grain damage was computed. Studies on morphological basis of resistance in pigeonpea against pod borers, data on certain morphological traits viz., flower colour, pod colour, pod size, pod constriction, pod surface sticky ness, pod hairy ness, pod wall thickness, pod form, seed colour, and seed colour pattern, size of the seed, seed shape and number of seed per pod etc. was recorded for the variations in incidence of pod borers damage. The uniformly developed ten pods from each genotype were collected randomly and used to assess the length and width of pods with the help of graph paper and expressed in centimeter per pod. Thickness of pod wall in ten pods was measured by using the vernier calipers and expressed in millimeter per pod.

The total number of pods and pods damaged by pod borers was recorded at maturity stage, from the randomly selected five plants. Pod borers damage to pods was quantified by expressing the number of pod borer damaged pods as a percentage of total number of pods. Pod damage by pod borer was identified by the presence of round, large bored holes in pods and a pin shaped hole and immature drying for pod fly. In order to ascertain the pod damage caused by pod borers viz., gram pod borer, Helicoverpa armigera (Hubner) and plume moth, Exelastis atomosa (Walshingham) and the pod fly, Melanagromyza obtusa (Malloch) were inspected on the basis of infestation pattern specified by Bindra and Jokhmola (1967) adopted and which was as follows for each pod borer.

Gram pod borer, $H$. armigera: The pod shells with relatively large and round holes indicate the boring by Helicoverpa caterpillar. Attacked pods with holes are devoid of excreta. Tur plume moth, E. atomosa : Holes made by the larva of plume moth are small or medium size as compared to those made by Helicoverpa larva, the pods showing holes opposite to seeds and without grains or partially eaten grains with blackish excreta were accounted for tur plume moth damage. Tur pod fly, M. obtusa: For separating the pods damaged by pod fly, the pods were examined externally as well as internally by dissecting them.

The damaged pods were brownish in colour with pin holes externally from which adult emerged. The grains damaged by maggot carried a mine below the testa and an ablong notch eaten into the grains. Many times puparium was found lying in the notch or in the pod. After the data converted into per cent damaged pods (PD) was worked out as per the formula given below (Gangwar et al., 2009).

Per cent Pod damage (\%)

Number of damaged pods

= -------------------- $\times 100$

Total number of pods

Statistical analysis of the data: The data was obtained on screening of restorers against pod borers and influence of morphological characters on pod damage and subjected to statistical analysis after suitable transformations for interpretation of the results. 


\section{Results and Discussion}

\section{Influence of morphological against pod borer of pigeonpea}

characters

The morphological characters of twenty six pigeonpea restorers were studied on the basis of morphological/ visual observations made during the crop growth period. The results of characters are presented in Table 1.

\section{Pod surface stickiness and pod color with streak}

All the screened pigeonpea restorer was found some were present and absent of pod surface stickiness. The characters as pod surface stickiness show relationship with the infestation of pod borers. Whereas, the pod color of different restorers of pigeonpea were as green with brown, purple and dark purple, green with reddish brown streak were found. These pods are green color with brown streak characters show relationship with the less infestation of pod borers. The pod form of different restorers of pigeonpea were found flat as well as cylindrical and cylindrical pod form show with the less infestation of pod borers.

The present findings are accordance with Tripathi et al., (1983) found that small green pods with streaks showed least damage (33\%) compared to green and large pods with streaks recorded less $(25.1 \%)$ damage compared to large green pods (33.8\%). Also with the accordance of Sanap (1992) reported that he did not found any role of flower colour in imparting resistance or susceptibility to pod borers.

\section{Pod wall thickness and pod length and width}

In regards the pod wall thickness it was observed that the pigeonpea restorers with more pod wall thickness, minimum seeds per pod as well as moderate length of pod and moderate width of pods were found minimum incidence of pod borers. The some exceptions were though had long pods, showed the low incidence of pod borer. This findings are in accordance with the Sahoo et al., (2002) reported that bigger the size of pods as higher incidence of pod borers except E. atomosa.

\section{Screening of pigeonpea promising restorers against pod borer}

Twenty six pigeonpea promising restorers representing four maturity groups viz., early, medium early, mid late and late having different growth habits were screened under natural infestation for their reaction against pod borers viz., H. armigera, E. atomosa, $M$. obtuse and Maruca vitrata etc. The observations on the pod damage of all restorers were recorded at the $50 \%$ flowering to maturity.

\section{Per cent pod damage}

The data pod damage by pod borer on pigeonpea promising restorers in Table 2, and data revealed significant differences among the restorers regarding pod damage by pod borers. The pod damage by pod borer was observed in the range of 7.53 to 36.02 per cent on the various restorers. The significantly least pod damage was reported on BDNHR-31-71 (7.53 per cent) which was at par with BDNHR-31-63 (7.88 per cent), BDNHR-3152 (9.57 per cent), BDNHR-11-3 (10.64 per cent), and BDNHR-31-23 (11.35 per cent), respectively.

The result in relation to pod damage by pod borer infesting on pigeonpea are pursuant to recorded by Rizwana Banu, et al., (2007) who revealed that field screening and evaluation of pigeonpea genotypes against pod borer (Helicoverpa armigera), they calculated the pod damage (\%) on the basis of number of pods examined and the number of infested 
pods marketable green pod yield of each genotype under natural pest infestation also recorded. On the basis of mean infestation, ICPL-3201 showed that lowest $(25 \%)$ pod damage and showed lowest susceptibility among the genotypes studied. It was followed by ICPL-3208 and ICPL-1964 showed lower pod damage. The rest of the genotype suffered higher pod damage to Helicoverpa armigera. Similarly, Kumar et al., (2011) conducted field trials during 2007-08 and 2008-09.

Among the 50 pigeonpea germplasm a wide range of variation of pod (18.33 to $47.00 \%$ ) and seed (16.43 to 48.44\%) damage by lepidopterous pod borers were recorded with average mean of 30.68 and $31.69 \%$, respectively. On the basis of pooled mean, two lines viz., ICP-2514 (18.33\%) and ICP-2454 (19.33\%) reveal resistance against the pod damage caused by pod fly, respectively whereas, based on seed damage ICP-2459 $(16.43 \%)$ and ICP-2155 (18.62\%) were categorized as resistant. Similarly, Rathod et al., (2013) reported on screening of different varieties of pigeonpea against pod borer complex. They were observed that BSMR-853 was found the least susceptible (1.39 larvae/plant) and it was at par with variety AGT-2(1.61 larvae/ plant).

The varieties ICPL-87119 was found highly susceptible with 5.63 larvae per plant. However, among all the varieties of pigeonpea, BSMR-853 recorded lower percent pod damage due to pod borer $(18.59 \%)$ which was at par with AGT-2 (20.9 \%). the highest pod damage was recorded on variety ICPL$87119(36.56 \%)$.in case of percent seed damage, among all the varieties of pigeonpea, BSMR-853 recorded lower percent seed damage due to pod fly $(7.50 \%)$ which was at par with AGT-2 (8.55\%). the highest pod damage was recorded on variety ICPL-87119. The pod damage due to pod fly, M. obtusa was observed in the range of 5.66 to 38.45 pod per cent on the restorers. The significantly least pod damage was reported on restorers BDNHR-9-1 (5.66 per cent) which was at par with BDNHR-31-71 (10.07 per cent). The present investigation was agreed with Paul et al., (2005) studied the pod fly infestation in pigeonpea in different dates of sowing and different stages of the crop and reported that the mean of 5 observations indicated 34.42, 28.03 and 32.42 and $31.97,47.85$ and 37.39 per cent infestation in bottom, middle and top tiers of canopy, respectively for plants of the successive two dates of sowing i.e. $8^{\text {th }}$ July and $21^{\text {st }}$ July.

Similarly, Meena et al., (2010) studied the seasonal incidence of pod fly on long duration pigeonpea and revealed that the major activity of pod fly in terms of infested pod/ plant was during $10^{\text {th }}$ and $8^{\text {th }}$ standard week during 200809 (57.0\%) and 2009-10 (28.5\%), respectively.

Maximum incidence of $M$. obtusa in terms of maggot population was recorded in $9^{\text {th }} \mathrm{SW}$ with population of 35.6 and 2.6 maggots/ plant, respectively. During 2008-2009, pupal activity of $M$. obtusa was maximum (39.2 pupae) in $12^{\text {th }} \mathrm{SW}$ and in $2009-10$ it was 9 pupae in the $11^{\text {th }} \mathrm{SW}$.

\section{Per cent grain damage}

The grain damage by pod borer was observed in the range of 1.89 to 13.25 per cent on the restorers. The least grain damage was reported on restorers BDNHR-31-52 (1.89 per cent) which was at par with BDNHR-31-90 (2.03 per cent) followed by BDNHR-31-71 (2.18 per cent), BDNHR-31-33 (2.84 per cent), BDNHR-31-23 (3.06 per cent), BDNHR-3163 (3.13 per cent), BDNHR-31-7 (3.38 per cent), and BDNHR-31-49 (3.54 per cent), respectively. 
Table.1 Morphological characters of different pigeonpea restorers

\begin{tabular}{|c|c|c|c|c|c|c|c|c|c|}
\hline \multirow[t]{2}{*}{ Sr. No. } & \multirow[t]{2}{*}{ Restorers } & \multicolumn{8}{|c|}{ Morphological characters of pigeonpea restorers } \\
\hline & & $\begin{array}{c}\text { Pod surface } \\
\text { stickiness }\end{array}$ & $\begin{array}{l}\text { Pod colour/ } \\
\text { streak }\end{array}$ & Pod form & $\begin{array}{c}\text { Pod wall } \\
\text { thickness }(\mathrm{mm})\end{array}$ & $\begin{array}{c}\text { Pod } \\
\text { Length } \\
(\mathbf{m m})\end{array}$ & $\begin{array}{l}\text { Pod width } \\
\quad(\mathrm{mm})\end{array}$ & $\begin{array}{c}\text { No. of } \\
\text { seed/pod }\end{array}$ & $\begin{array}{l}\text { Seed Size } \\
\quad(\mathbf{m m})\end{array}$ \\
\hline 1 & BDNHR-1 & Present & Green & Flat & 0.49 & 50.55 & 9.30 & 3.93 & 12.67 \\
\hline 2 & BDNHR-22 & Present & Green/ purple & Cylindrical & 0.59 & 54.10 & 7.54 & 3.67 & 9.67 \\
\hline 3 & BDNHR-21 & Present & Green/ brown & Cylindrical & 0.49 & 48.66 & 7.06 & 3.00 & 10.00 \\
\hline 4 & BDNHR-24 & Present & Green/ brown & Cylindrical & 0.48 & 44.52 & 7.87 & 3.40 & 13.00 \\
\hline 5 & BDNHR-31 & Present & Purple & Cylindrical & 0.38 & 55.76 & 9.50 & 3.80 & 11.33 \\
\hline 6 & BDNHR-31-7 & Absent & Green & Flat & 0.42 & 53.75 & 9.33 & 2.60 & 9.33 \\
\hline 7 & BDNHR-31-14 & Absent & Green & Cylindrical & 0.41 & 47.01 & 8.59 & 3.87 & 11.33 \\
\hline 8 & BDNHR-31-25 & Present & Green/ brown & Cylindrical & 0.43 & 49.24 & 8.95 & 3.93 & 14.00 \\
\hline 9 & BDNHR-31-32 & Absent & Green & Cylindrical & 0.26 & 60.46 & 9.78 & 3.00 & 12.00 \\
\hline 10 & BDNHR-31-34 & Absent & Green & Flat & 0.47 & 55.13 & 8.91 & 3.40 & 11.67 \\
\hline 11 & BDNHR-31-49 & Absent & Green/ brown & Flat & 0.47 & 60.07 & 11.02 & 2.80 & 12.33 \\
\hline 12 & BDNHR-15-1 & Present & Green & Cylindrical & 0.37 & 60.37 & 9.09 & 3.47 & 11.67 \\
\hline 13 & BDNHR-17-1 & Present & Green/ brown & Cylindrical & 0.39 & 50.56 & 8.18 & 3.00 & 12.33 \\
\hline 14 & BDNHR-31-4 & Absent & Green/ brown & Flat & 0.38 & 51.70 & 9.68 & 3.60 & 12.00 \\
\hline 15 & BDNHR-31-21 & Present & Green /purple & Flat & 0.32 & 52.21 & 10.13 & 3.87 & 13.00 \\
\hline 16 & BDNHR-31-23 & Present & Green/ purple & Flat & 0.51 & 54.94 & 9.79 & 3.60 & 12.33 \\
\hline 17 & BDNHR-31-33 & Absent & Green & Flat & 0.40 & 47.78 & 9.05 & 3.67 & 13.33 \\
\hline 18 & BDNHR-31-52 & Present & Green/ purple & Cylindrical & 0.49 & 51.39 & 10.17 & 3.80 & 14.00 \\
\hline 19 & BDNHR-31-63 & Present & Green/ brown & Cylindrical & 0.55 & 58.36 & 11.02 & 3.60 & 13.00 \\
\hline 20 & BDNHR-31-71 & Present & Green /brown & Cylindrical & 0.38 & 55.17 & 9.05 & 4.00 & 12.33 \\
\hline 21 & BDNHR-9-1 & Present & Dark/ purple & Cylindrical & 0.25 & 54.08 & 9.29 & 3.87 & 12.00 \\
\hline 22 & BDNHR-11-3 & Absent & Green & Flat & 0.51 & 64.04 & 9.67 & 3.73 & 13.67 \\
\hline 23 & BDNHR-31-15 & Present & Green/ purple & Cylindrical & 0.17 & 50.46 & 8.05 & 2.73 & 11.33 \\
\hline 24 & BDNHR-31-90 & Present & Green/ purple & Flat & 0.45 & 44.66 & 11.76 & 3.67 & 13.00 \\
\hline 25 & BDNHR-31-91 & Present & Green/ purple & Cylindrical & 0.36 & 49.89 & 9.71 & 2.80 & 11.00 \\
\hline 26 & BDN- 711 & Absent & $\begin{array}{c}\text { Green /reddish } \\
\text { brown }\end{array}$ & Cylindrical & 0.47 & 50.87 & 10.05 & 3.80 & 13.00 \\
\hline
\end{tabular}


Int.J.Curr.Microbiol.App.Sci (2019) 8(12): 1016-1025

Table.2 Screening of pigeonpea restorers against pod borers infestation

\begin{tabular}{|c|c|c|c|c|c|c|}
\hline \multirow{2}{*}{$\begin{array}{l}\text { Sr. } \\
\text { No. }\end{array}$} & \multirow[t]{2}{*}{ Restorers } & \multicolumn{2}{|c|}{ Per cent Pod damage } & \multicolumn{2}{|c|}{ Per cent grain damage } & \multirow{2}{*}{$\begin{array}{c}\text { Grain yield } \\
\text { (kg/ha) }\end{array}$} \\
\hline & & Pod borer & Pod fly & Pod borer & Pod fly & \\
\hline 1 & BDNHR-1 & $18.13(25.09)$ & $24.58(29.70)$ & $4.85(12.72)$ & $13.13(21.22)$ & 1383 \\
\hline 2 & BDNHR-22 & $32.17(34.54)$ & $30.58(33.49)$ & $8.45(15.88)$ & $16.42(23.82)$ & 1466 \\
\hline 3 & BDNHR-21 & $31.93(34.34)$ & $32.96(34.99)$ & $8.50(16.90)$ & $14.15(22.00)$ & 1764 \\
\hline 4 & BDNHR-24 & $20.30(26.74)$ & $22.15(28.05)$ & $4.94(12.78)$ & $5.25(13.19)$ & 1686 \\
\hline 5 & BDNHR-31 & $23.78(29.14)$ & $31.73(34.25)$ & $8.04(16.44)$ & $24.07(29.33)$ & 1131 \\
\hline 6 & BDNHR-31-7 & $13.82(21.69)$ & $21.41(27.53)$ & $3.38(10.41)$ & $14.19(22.06)$ & 1257 \\
\hline 7 & $\begin{array}{c}\text { BDNHR-31- } \\
14\end{array}$ & $36.01(36.87)$ & $34.30(35.82)$ & $8.85(17.28)$ & $16.42(23.87)$ & 1659 \\
\hline 8 & $\begin{array}{l}\text { BDNHR-31- } \\
25\end{array}$ & $28.86(32.46)$ & $37.42(37.71)$ & $8.81(17.22)$ & $19.31(26.00)$ & 1302 \\
\hline 9 & $\begin{array}{l}\text { BDNHR-31- } \\
32\end{array}$ & $28.17(31.98)$ & $29.34(32.73)$ & $8.44(16.79)$ & $17.98(24.96)$ & 1293 \\
\hline 10 & $\begin{array}{l}\text { BDNHR-31- } \\
34\end{array}$ & $30.90(33.72)$ & $34.70(36.06)$ & $7.68(16.07)$ & $19.58(26.25)$ & 1653 \\
\hline 11 & $\begin{array}{c}\text { BDNHR-31- } \\
49\end{array}$ & $16.14(23.64)$ & $20.84(27.06)$ & $3.54(10.71)$ & $16.07(23.63)$ & 1602 \\
\hline 12 & BDNHR-15-1 & $21.79(27.76)$ & $20.10(26.58)$ & $5.32(13.29)$ & $24.60(29.71)$ & 1530 \\
\hline 13 & BDNHR-17-1 & $35.20(36.38)$ & $32.84(34.93)$ & $11.85(20.12)$ & $23.16(28.74)$ & 1251 \\
\hline 14 & BDNHR-31-4 & $21.15(27.32)$ & $23.08(28.66)$ & $7.27(15.62)$ & $12.53(20.72)$ & 1215 \\
\hline 15 & $\begin{array}{c}\text { BDNHR-31- } \\
21\end{array}$ & $24.54(29.60)$ & $28.32(32.08)$ & $3.91(11.32)$ & $10.26(18.64)$ & 1344 \\
\hline 16 & $\begin{array}{c}\text { BDNHR-31- } \\
23\end{array}$ & $11.35(19.53)$ & $17.14(24.36)$ & $3.06(9.93)$ & $6.83(15.07)$ & 1783 \\
\hline 17 & $\begin{array}{l}\text { BDNHR-31- } \\
33\end{array}$ & $12.27(20.45)$ & $11.70(19.83)$ & $2.84(9.50)$ & 9.38 (17.69) & 1855 \\
\hline 18 & $\begin{array}{c}\text { BDNHR-31- } \\
52\end{array}$ & $9.57(17.73)$ & $10.71(18.99)$ & $1.89(7.81)$ & 7.07 (15.32) & 2208 \\
\hline 19 & $\begin{array}{c}\text { BDNHR-31- } \\
63\end{array}$ & 7.88 (16.17) & $14.74(22.44)$ & $3.13(9.98)$ & $4.43(11.81)$ & 1871 \\
\hline 20 & $\begin{array}{c}\text { BDNHR-31- } \\
71\end{array}$ & $7.53(15.83)$ & $10.07(18.15)$ & $2.18(8.35)$ & $3.28(10.29)$ & 1935 \\
\hline 21 & BDNHR-9-1 & $12.5(20.67)$ & $5.66(13.64)$ & $3.74(11.02)$ & $6.73(14.93)$ & 1689 \\
\hline 22 & BDNHR-11-3 & $10.64(18.92)$ & $11.13(19.13)$ & $3.65(10.93)$ & $5.11(13.02)$ & 2250 \\
\hline 23 & $\begin{array}{c}\text { BDNHR-31- } \\
15\end{array}$ & $23.76(29.14)$ & $28.33(32.03)$ & $5.89(14.04)$ & $7.52(15.89)$ & 1382 \\
\hline 24 & $\begin{array}{c}\text { BDNHR-31- } \\
90\end{array}$ & $14.27(22.16)$ & $13.09(21.09)$ & $2.03(8.01)$ & 3.07 (9.99) & 1553 \\
\hline 25 & $\begin{array}{c}\text { BDNHR-31- } \\
91\end{array}$ & $21.69(27.75)$ & $28.33(32.13)$ & $5.63(13.66)$ & $9.97(18.29)$ & 1401 \\
\hline \multirow[t]{4}{*}{26} & BDN- 711 & $36.02(36.87)$ & $38.45(38.31)$ & $13.25(21.28)$ & $32.21(34.58)$ & 1808 \\
\hline & $\mathrm{SE}(\mathrm{m}) \_+$ & 1.57 & 1.76 & 1.02 & 1.23 & 107.52 \\
\hline & $\mathrm{CD}$ at $5 \%$ & 4.46 & 5.00 & 2.90 & 3.48 & 304.12 \\
\hline & CV\% & 10.20 & 10.76 & 13.28 & 10.45 & 1173 \\
\hline
\end{tabular}

Figures in parentheses are angular transformed values. 
The result in relation to grain damage of $H$. armigera infesting pigeonpea are pursuant to the observations recorded by Kumari, et al., (2010) evaluated the genotypes ICPL 187-1, ICP 7203-1, ICPL 98008, T21, ICP 7035, ICPL 332 exhibited moderate levels of resistance to Helicoverpa armigera across planting dates, although there were if you exceptions. ICPL 187-1, ICP 7203-1, ICPL 84060, ICPL 87119 and ICPL 332 also showed better grain yield potential than the susceptible checks, ICPL 87 and ICPL 87091. all the genotypes where stable in their reaction to pod borer damage based on visual damage rating (except ICPL 87119 and ICPL 84060), but unstable for $\%$ pod damage. The grain damage by pod fly $M$. obtusa was observed in the range of 3.07 to 32.21 per cent on the restorers. The significantly least grain damage was reported on restorers BDNHR-31-90 (3.07 per cent) which was at par with BDNHR-31-71 (3.28 per cent) followed by BDNHR-31-63 (4.43 per cent), BDNHR-11-3 (5.11 per cent) and BDNHR-24 (5.25 per cent), respectively. The highest grain damage of pod fly M. obtusa was recorded on check as BDN-711 (32.21 percent).

The present findings are accordance with Rathod et al., (2013) reported on screening of different varieties of pigeonpea against pod borer complex. BSMR-853 recorded lower percent seed damage due to pod fly $(7.50 \%)$ which was at par with AGT-2 (8.55\%).

\section{Grain yield}

The grain yield of different restorers was observed in the range of 1131 to $2250 \mathrm{~kg} / \mathrm{ha}$. The significantly maximum grain yield was reported on restorers BDNHR-11-3 (2250 $\mathrm{kg} / \mathrm{ha}$ ) which was statistically at par with BDNHR-31-52 (2208 kg/ha). These two were found significantly superior over the other entries. The next set of progenies were found maximum grain yield on BDNHR-31-71
(1935 kg/ha), BDNHR - 31-63 (1871 kg/ha), BDNHR-31-33 (1855 kg/ha), BDN-711 (1808 $\mathrm{kg} / \mathrm{ha})$ and BDNHR-31-23 (1783 kg/ha), respectively. The lowest grain yield were recorded on BDNHR-31 (1131 kg/ha). The present finding are accordance with Raut et al., (1993) They observed entry H-84-14 had lowest grain infestation whereas, maximum damage was recorded in ICPL-317. The CORG-13, H-84-14, CO-5, ICPH-8, МTH-6, BON-33 and MTH-66 gave higher yield than the other entries. The total loss in grain yield varied from 8.68-54.84 per cent. On the basis of the above investigation it may be concluded that host plant resistance plays a very important role in governing the pest infestation level in pigeonpea and screening is an appropriate method to identify resistant genotype. On morphological characters like maximum pod wall thickness, maximum numbers of seeds per pods, maximum pod width characters were found to be least preferred as compared to minimum pod wall thickness, short pod wall thickness and minimum width of pods which having more susceptible restorers against pod borer complex of pigeonpea.

\section{Acknowledgement}

The authors are thankful to the Associate Dean \& Principal, College of Agriculrure Badnapur and Officer Incharge Agril. Research Station Badnapur, VNMKV Parbhani for providing the necessary facilities during the course of investigation.

\section{References}

Anonymous, 2018. Annual Report of Research Work on Pulses 2017-18. ARS, Badnapur VNMKV, pp. VI.

Bindra, O.S. and Jakhmola, S.S. 1967. Pod fly incidence and seed damage in pigeonpea in Madhya Pradesh. Indian Agric. Sci. 27: 177 -180. 
Gangwar, L.K., Bajpai, G. C., Kerkhi S. A. and Sachan S. K. 2009. Pod borer susceptibility reaction in interspecific hybrids of pigeonpea. Indian Journal of Genet., 69(1): 58-61

Green, P. W. C., Stevenson, P. C., Simmonds M. S. J. and Sharma, H.C. 2003. Phenolic compounds on the pod surface of pigeonpea, Cajanus cajan, mediate feeding behaviour of larvae of Helicoverpa armigera. Journal of chemical Ecology, 29(4): 811-821.

Fitt, G.P. 1989. The ecology of Heliothis to agro-ecosystems. Annual Review of Entomology, 34: 17-52.

Kumar, A., Lall, P. V. and Lal, D. 2011. Abiotic factors and pigeonpea pod fly, Melanagromyza obtusa (Malloch). Indian Journal of Entomology 73(1): 59-62.

Kumari, A. D., Reddy, J.D. and Sharma, H.C. 2010. Stability of resistance to pod borer, Helicoverpa armigera in pigeonpea. Indian J. of Plant Protection. 38(1):6-12.

Lal, S. S. and Katti, G. 1998. Integrated Pest management of pod borer complex infesting pigeonpea. IPM system in agriculture. Aditya Books Pvt. Ltd. New Delhi, India 4, Pulses.PP: 79-128.

Meena, B. M., Srivastava, C. P. and Sharma, R. P. 2010. Seasonal incidence of pod fly, Melanagromyza obtusa (Malloch) on long duration pigeonpea, (Cajanus cajan L.). Annals of Plant Protection Sciences 18(2): 394-399.

Paul, S. K., Jha, S. and Bandyopadhyay, B. 2005. Infestation characteristics of pod fly (Melanagromyza obtusa) (Agromyziidae: Diptera) on pigeonpea (Cajanus cajan) in West Bengal. Indian Journal of Agricultural Sciences 75(5): 301-302.

Rathod N. P., Vala, G. S., Dudhat A. S. and Kachhadiya N. M. 2013. Screening of different varieties of pigeonpea against pod borer complex. International journal of plant protection, 7(1) 154156.

Raut S B, Nawale R N and Mote U N 1993. Field screening of pigeonpea germplasm against pod bore complex. Agriculture Science Digest 13(1): 1719.

Sahoo B K, Patnaik H P and Mishra B K 2002. Field screening of early maturing pigeonpea cultivars against the pod borers in Orissa. Indian Journal of Plant Protection 30(1): 1315.

Sanap M. M.1992. Studies on incidence, varietal reaction and chemical control of pigeonpea pod borers. $\mathrm{Ph}$. D. (Agri.), thesis submitted to the Mahatma Phule Krishi Vidyapeeth, Rahuri.

Shanower, T.G., Yoshida, M. and Peter, A. J. 1997. Survival, growth, fecundity and behaviour of Helicoverpa armigera (Lepidoptera: Noctuidae) on pigeonpea and two wild Cajanus species. Journal of Economic Entomology, 90: 837-841.

Sharma, V. K. and Pandey, S. N. 1993. Estimation of avoidable yield losses due to borer complex in early, medium and late maturing cultivars of pigeonpea. Indian J. Ent., 55(2) : 174177.

Shrivastava, Nikhil, Odak, S. C., Das, S. B. and Goswami, H. 1993. Studies on susceptibility of pigeonpea cultivars to some pod infesting insects. JNKVV Res. J., 27(1): 143-147.

Singhal, V. 2003. Indian Agriculture, Indian Economics Data Research Center, New Delhi. PP : 180-181.

Srilaxmi, K. and R. Paul 2010. Diversity of insect pests of pigeonpea [Cajanus cajan (L.) Millsp.] and their succession in relation to crop phenology in Gulbarga, Karnataka. The Ecoscan, 4: 273-276. 
Sujithra, M. and Chander S. 2014. Seasonal incidence and damage of major insect pests of pigeonpea, Cajanus cajan (L.). Indian Journal of Entomology, 76 : 202-206.

Rizwana Banu. M., Muthiah. A.R., Ashok. S., 2007. Host Plant Resistant Mechanism to Podborer (Helicoverpa armigera) in Pigeonpea. Asian Journal of Plant Sciences 6(1) : 193-194.

Tripathi, R. K. and Purohit, M. L. 1983. Pest damage on pigeonpea in relation to pod size and colour. Legume Research 6(2): 103-104.

\section{How to cite this article:}

Sukanya Machanwar and Sanjeev Bantewad. 2019. Assessment of Pigeonpea Restorers on Morphological Basis of Host Plant Resistance against Pod Borers. Int.J.Curr.Microbiol.App.Sci. 8(12): 1016-1025. doi: https://doi.org/10.20546/ijcmas.2019.812.130 